\title{
Role of NGO in Empowering Women through Microfinance: A Conceptual Study
}

\author{
Manju Pathania Biswas ${ }^{1}$, Dr. M Rama Mohan Rao ${ }^{2}$ \\ ${ }^{I}$ Research Scholar, Department of Entrepreneurship, Gitam Institute of Management, GITAM University, \\ Visakhapatnam, AP, India -530045. \\ ${ }^{2}$ (Associate Professor, Department of Entrepreneurship, Gitam Institute of Management, GITAM University, \\ Visakhapatnam, AP, India -530045.
}

\begin{abstract}
Empowerment is a multi-dimensional process that helps women to gain authority and self realization in improving their life standards. Women should realize that they have constitutional rights to good quality health care, financial security, and access to knowledge, information, education and equal opportunities for the girl in the society. Empowerment signifies a change from a status of failure to recognition and success. Empowerment also systematizes their lives and resources. Microfinance sector has grown rapidly over the past two decades and has helped women to gain economic empowerment and improve quality of their life. Development of Micro Entrepreneurship through microfinance can help reduce the problem of unemployment and several social problem that go with it.
\end{abstract}

Keywords: Women Empowerment, Microfinance, NGO, Micro-Entrepreneurship, poverty alleviation.

\section{Introduction:}

"Microfinance is the provision of financial services to low-income clients or solidarity lending groups including consumers and the self-employed, who traditionally lack access to banking and related services."

Microfinance is not just about giving micro credit to the poor rather it is an economic development tool whose objective is to assist poor to work their way out of poverty. It covers a wide range of services like credit, savings, insurance, remittance and also non-financial services like training, counseling etc.

With financial inclusion emerging as a major policy objective in the country, Microfinance has occupied centre stage as a promising channel for extending financial services to unbanked sections of population. The emergent women entrepreneurs and their contribution to the nation's economy is root to their empowerment. Microfinance programs have significant potential for contributing to women's economic, social and political empowerment in developed and developing countries. Today agencies like Government as well as Nongovernment Organizations are involved in micro-finance development initiatives.

Features of Microfinance

- Borrowers are from the low income group

- Loans are of small amount called as micro loans

- Short duration loans

- Loans are offered without Collateral

- High frequency of repayment

- Loans are generally taken for income generation purpose

Though many central government and state government poverty alleviation programs are currently active in India, microfinance plays a major contributor to financial inclusion. In the past few decades it has helped out remarkably in eradicating poverty. Reports show that people who have taken microfinance have been able to increase their income and hence the standard of living.

The importance of women to the economic development of India was first recognized during the country's struggle for independence. Empowerment is a social action process that promotes participation of people, organization and communities in gaining control over their lives in their community. There is urgent need of empowering women especially in rural areas.

Women in rural India lived in virtual isolation, unable to access even the most basic of services. But, with the formation of Women's Self-Help Groups, these women are now achieving social and physical mobility. It is recognized that while the empowerment of women is a process that will not happen automatically, SHG is a suitable means for the empowerment of women. The impacts of SHGs on socio-economic status of women were found significant. 
Microfinance programmes are currently being promoted as a key strategy for simultaneously addressing both poverty alleviation and women's empowerment. Where financial service provision leads to the setting up or expansion of micro-enterprises there are a range of potential impacts including:

1. Increasing women's income levels and control over income leading to greater levels of economic independence.

2. Access to networks and markets giving wider experience of the world outside the home, access to information and possibilities for development of other social and political roles.

3. Enhancing perceptions of women's contribution to household income and family welfare, increasing women's participation in household decisions about expenditure and other issues and leading to greater expenditure on women's welfare.

4. More general improvements in attitudes to women's role in the household and community.

As seen in the diagram below NGO's constitute a feasible alternative to government as a channel of developing countries.

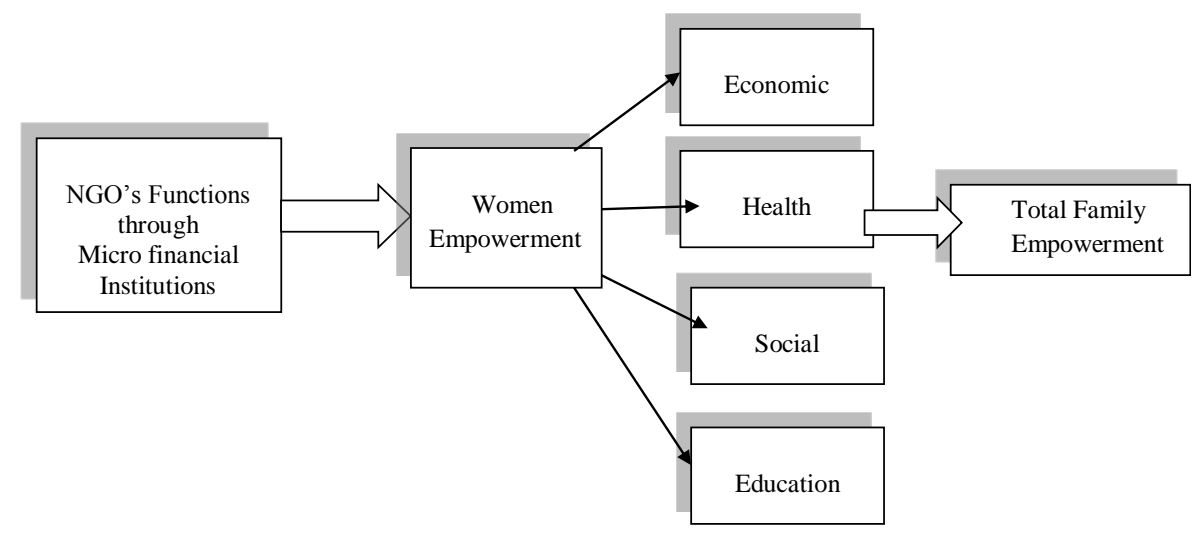

II. Status Of Microfinance In India

Microfinance sector has traversed a long journey from micro savings to microcredit and then to micro enterprises and it has now entered the field of micro insurance, micro pension. Financial institutions in the country continue to play a leading role in the microfinance program for nearly two decades now. They have joined hands proactively with informal delivery channels to give microfinance sector the necessary momentum. A number of field researches have been conducted by various agencies to study the impact of microfinance on socio-economic aspects of the consumers. In spite of the impressive figures, the supply side of microfinance in India is still presently grossly inadequate to fill the gap between demand and supply but it holds the promise to act as a great opportunity for the financial sector and the economy as a whole. Microfinance is facing a crucial time when it hopes to become part of the financial delivery system in India and be part of the financial inclusion agenda.

Majority of the poor are excluded from financial services. This is due to the following reasons

1. Bankers feel that it is fraught with risks and uncertainties.

2. High transaction costs

3. Unfavorable policies like caps on interest rates which effectively limits the viability of serving the poor.

4. Difficulty in accessing low cost on-lending funds (as of now they are unable to offer savings services in a legitimate manner)

Status of Microfinance in 2013:

- Major trend is RBI being able to put forward a very significant set of regulatory guidelines which seem to have given hope to the sector that orderly growth is possible.

- Big NBFC MFIs have regained market confidence and picked momentum in client outreach and loans outstanding. Bank credit eased for MFIs and SHGs as well.

- Emergence of new forms of partnerships (SHGs - MFIs-government banks-tech companies - BCs) has been encouraging.

- Compound annual growth rate - Suffered after 2010 for both SBLP and MFIs

• 


\section{Key Issues Of Microfinance In India}

Low outreach: the outreach of microfinance is India is only $8 \% . \mathrm{t}$ has been observed that the program is focused on primarily on rural women. It has been argued that women are reliable clients as they have better saving potential and their repayment performance is also better than men. This has inclined the micro financial institutions towards women. However since not much women apply for loans the outreach is reduced (Sarumathi, S. and Mohan K., 2011).

High Rate of Interest: The interest rate charged by MFIs is very high which the poor are unable to payback. Since most the MFIs in the country are privatized and do not receive and subsidized credit, in order to recover their cost they pass their burden to back to borrowers (Thorat, Y.S.P., 2006).

Low Client Retention: The client retention rate is also only $28 \%$ in India. This is due to lack of information and proper education about the services available to the poor $r$ (Thorat, Y.S.P., 2006).

Geographic Barriers: 50\% of the Indian reside in rural part and 60\% of the MFIs functioning in the nation are not able to reach and communicate with the secluded areas which in turn also affect the outreach of these services (Thorat, Y.S.P., 2006).

Poor Population in Urban Areas is neglected by MFIs: There are currently 800 MFIs in the country out of which only 6 MFIs are paying attention to the needs of urban poor which is a very low percentage. The rate of urbanization is increasing day by day which also lead to rapid rise in percentage of urban poor (Thorat, Y.S.P., 2006).

Loan Collection Method: Loan Collection Method is found an issue that creates a problem in growing the organization. Around 55\% of MFIs agrees that due to weak law and legislation they are not able to make their loan collection system as effective as they want to do so.

Fraud: Fraud is an issue that creates a problem in growth and expansion of the organization because its percentage is around 67\% in MFIs. Mismanagement of loans on the part of the clients creates the problem of fraud and financial embezzlement on the part of clients.

Increased Competition: Increased competition is an issue that creates a problem in growth and expansion of the organization because its percentage is around $72 \%$. As there has been growth in the banking sector with regard to the loan facilities therefore there is a greater competition among such institutions.

\section{Role Of Non-Governmental Organizations:}

NGO's organize training programmes for the income generating activities (IGA).

Some of the NGOs' functions and advantages, according to Streeten (1997) are:

(1) They are good at reaching and mobilizing the poor and remote communities;

(2) They help empower poor people to gain control of their lives, and they work with and

Strengthen local institutions;

(3) They carry out projects at lower costs and more efficiently than the government agencies and (4) they promote sustainable development.

In India there are some people who still don't have a savings bank account and are deprived of all banking services. They need financial services to fulfill their needs like consumption, building of assets and protection against risk. Microfinance institutions serve as a supplement to banks. These institutions not only offer micro credit but they also provide other financial services like savings, insurance, remittance and nonfinancial services like individual counseling, training and support to start own business in a convenient manner. The borrower receives all these services at their door step and in most of the cases with a repayment schedule of borrower's convenience.

In India microfinance is typically defined as the provision of saving, credit and other financial services and products of very small amounts to the poor in rural, semi-urban or urban areas for enabling them to raise their income levels and improve living standards (NABARD, 2004). In addition to promoting the establishment or growth of micro enterprises, microfinance can increase the standard of living of the economically active poor, improve their access to health care and education, reduce vulnerability and promote the empowerment of women and marginalized groups. There are many successful women organizations working for the overall upliftment of the rural women like Shri Mahila Griha Udyog lijjat Papad (1959), SEWA established in 1972 has various credit programmes for women who earn a living through their own labor or small businesses. Since the 1970s, many women's organizations world-wide have included credit and savings, both as a way of increasing 
women's incomes and to bring women together to address wider gender issues. The 1980s saw the emergence of poverty-targeted micro-finance institutions like Grameen Bank. Rashtriya Mahila Kosh (RMK), a govt. organization for women established in 1993. Many of these programmes see themselves as empowermentoriented. In the 1990s, a combination of evidence of high female repayment rates and the rising influence of gender lobbies within donor agencies and NGOs led to increasing emphasis on targeting women in microfinance programmes.

In developing countries certain programs have emerged that specializes in supplying small capital loans to low-income entrepreneurs. In many of these programs a large percentage of borrowers are women. For example, based on a 1996 survey of microfinance institution around the world, the World Bank estimated that $61 \%$ of all clients were women (World Bank, 1997). High rate of women participation have raised a number of research questions and have in turn, inspired a growing number of empirical investigations.

\section{Entrepreneurship Development Among Rural Women Through Micro Credit/Micro} Finance:

SHGs are of recent origin in rural India to helping more than 17 million women from villages improve their incomes, educate their children, and buy assets. SHGs have also helped women campaign against oppressive social practices and become a force of development in their villages. Before 1990s, credit schemes for rural women were almost negligible. The concept of women's credit was born on the insistence by women oriented studies that highlighted the discrimination and struggle of women in having access to credit.

Micro credits are enough for innovative and hard working micro entrepreneurs to start small business such as making handicraft items. From the income of these small businesses the borrowers of micro credit can enjoy better life, food, shelter, health care and education for their families and above all these small earnings will provide a hope for better future. There are certain misconceptions about the poor rural women that they need loan at subsidized rates of interest on soft terms, they lack education, skills, capacity to save, creditworthiness and therefore are not bankable. The experiences of several SHGs reveal that rural women are actually efficient. Availability of timely and adequate credit is essential for them to undertake any economic activity rather than credit subsidy.

In rural areas the women micro entrepreneurs continue to produce the traditional designs for local markets. Women in SHGs produce a large variety of essential products, village crafts and homemade snack foods. Many are engaged in retail trading of groceries and textiles. These enterprises represent a substantial supply resource for semi-urban and urban markets. SHGs are also viable organized set up to disburse micro credit to the needy entrepreneur women and encouraging their promotion of poverty alleviation activities and programmes. Vast sections of the rural poor are even now deprived of the basic amenities, opportunities and oppressed by social customs and practices. Several programmes were implemented by various governments and nongovernmental organizations to uplift them both economically and socially. It has been an accepted premise that women were not given enough opportunities to involve themselves in the decision making process of the family as well as in the society. Hence, women were the main target groups under SHG programme. Microfinance can provide an effective way to assist and empower poor women, who make up a significant proportion of the poor and suffer disproportionately from poverty.

Access to savings and credit facilities strengthens women in economic decisions. It also improves their skills, knowledge and support networks as well as enhancing their status in the community. Increasing women's access to microfinance has led to social and political empowerment. Poverty alleviation and women empowerment are seen as two sides of the same coin and it is the only way to bring wider changes in gender inequality

\section{Future Of Microfinance And Empowering Women}

Developing women's leadership is important to deliver the promise of microfinance in alleviating poverty in the continent. Increasing women representation in microfinance and helping women develop the leadership skills to become innovators in their sector is the key to moving microfinance to a new level. Strategies should be put in place targeting women flexible microfinance delivery; services that complement gender; structures for participation; mechanisms for representation; inter-organizational links and institutionalized gender guidelines gendering all policy; gender equality within institutions; incentives for equity.

The high illiteracy rate among women in India requires governments and microfinance institutions to be proactive in organizing forums for educating women about their rights. To get fully empowered economically, women need to do more than just access finance. They need gender parity, insurance, education, healthcare and housing to help them spiral upwards.

Although micro-finance can make a contribution to empowerment of women, this cannot be assumed to be an automatic outcome. There underlies the course of a good approach to solving the incapacitation of the 
poor women in rural and disadvantaged areas of India to move out of poverty. For this to materialize, the women must develop the capacity to generate and maintain their means of livelihood and produce excess that will eventually lead to savings.

\section{Conclusion:}

The Indian microfinance sector has grown by leaps and bounds during the first decade of the twenty first century. A lot of changes have been seen during the last ten years on how the microfinance institutions function. Many transformed to for-profit legal forms and MFIs overall continue their efforts to become more efficient and productive. SBLP has also grown exponentially and is considered as the single largest microfinance programme globally. However, in this quest for growth and expansion the essence of microfinance as a programme for reaching the poor and excluded has lost its focus.

\section{References:}

[1]. Lalitha, N. and B.S. Nagarajan( 2002) : Self-help Groups in Rural Development (New Delhi, Dominant Publishers and Distributors).

[2]. World Bank, (1997): Sustainable Banking with the Poor: An Inventory of Microfinance Institutions in Latin America and the Caribbean. World Bank Publication, Washington, DC.

[3]. Streeten P 1997. Non-governmental Organizations and Development. Annals of the American Academy of Political and Social Science, 554: 193-210

[4]. Biswas T Women Empowerment Through Micro Finance - A Boon For Development

[5]. Cheston $\mathrm{S}$ and Kuhn L,Empowering Women Through Micro Finance

[6]. Dhar, P.K.(2007). "Indian Economy and its Growing Dimensions", Kalyani Publishers, Head office Ludhiana

[7]. Sarumathi, S. and Mohan K., (2011). Role of Micro Finance in Women's Empowerment", Journal of Management and Science 1(1): $1-10$

[8]. Thorat, Y.S.P., (2006). Microfinance in India; Sectoral issues and challenges. Towards a sustainable microfinance outreach in India, pp: $27-42$

[9]. http://agropedia.iitk.ac.in/content/rural-women-empowerment-through-microfinance

[10]. NABARD Website : www.nabard.org 